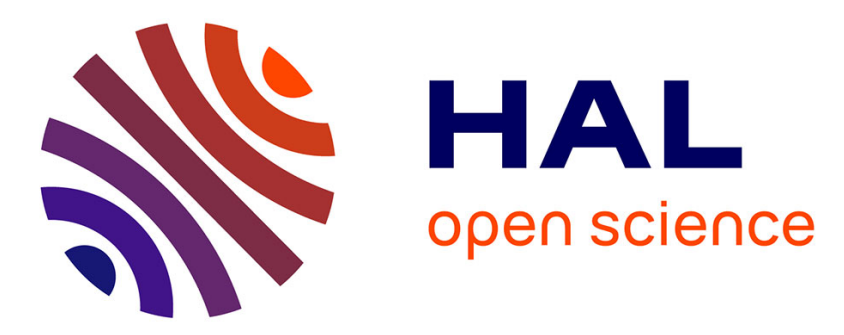

\title{
Overabundant ungulates in French Sologne? Increasing red deer and wild boar pressure may not threaten woodland birds in mature forest stands
}

Marie Baltzinger, Anders Mårell, Frédéric Archaux, Thomas Perot, Franck Leterme, Marc Deconchat

\section{To cite this version:}

Marie Baltzinger, Anders Mårell, Frédéric Archaux, Thomas Perot, Franck Leterme, et al.. Overabundant ungulates in French Sologne? Increasing red deer and wild boar pressure may not threaten woodland birds in mature forest stands. Basic and Applied Ecology, 2016, vol. 17 (n 6), pp. 552-563. 10.1016/j.baae.2016.04.005 . hal-01408523

\section{HAL Id: hal-01408523 \\ https://hal.science/hal-01408523}

Submitted on 5 Dec 2016

HAL is a multi-disciplinary open access archive for the deposit and dissemination of scientific research documents, whether they are published or not. The documents may come from teaching and research institutions in France or abroad, or from public or private research centers.
L'archive ouverte pluridisciplinaire HAL, est destinée au dépôt et à la diffusion de documents scientifiques de niveau recherche, publiés ou non, émanant des établissements d'enseignement et de recherche français ou étrangers, des laboratoires publics ou privés. 


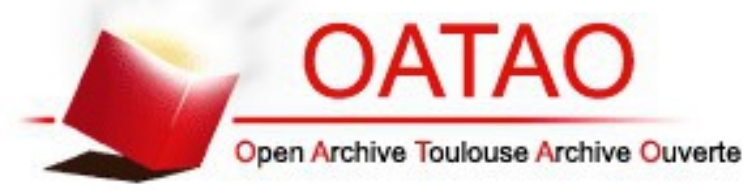

\section{Open Archive TOULOUSE Archive Ouverte (OATAO)}

OATAO is an open access repository that collects the work of Toulouse researchers and makes it freely available over the web where possible.

This is an author-deposited version published in : http://oatao.univ-toulouse.fr/ Eprints ID : 16254

To link to this article : DOI :10.1016/j.baae.2016.04.005

URL : http://dx.doi.org/10.1016/j.baae.2016.04.005

To cite this version : Baltzinger, Marie and Marell, Anders and Archaux, Frédéric and Pérot, Thomas and Leterme, Franck and Deconchat, Marc Overabundant ungulates in French Sologne? Increasing red deer and wild boar pressure may not threaten woodland birds in mature forest stands. (2016) Basic and Applied Ecology, vol. 17 ( $\mathrm{n}^{\circ}$ 6). pp. 552-563. ISSN 1439-1791

Any correspondance concerning this service should be sent to the repository administrator: staff-oatao@,listes-diff.inp-toulouse.fr 


\title{
Overabundant ungulates in French Sologne? Increasing red deer and wild boar pressure may not threaten woodland birds in mature forest stands
}

\author{
Marie Baltzinger ${ }^{\mathrm{a}, *}$, Anders Mårell ${ }^{\mathrm{a}}$, Frédéric Archaux ${ }^{\mathrm{a}}$, Thomas Pérot ${ }^{\mathrm{a}}$, \\ Franck Leterme $^{\mathrm{b}}$, Marc Deconchat ${ }^{\mathrm{c}}$ \\ ${ }^{\mathrm{a}}$ Irstea, les Barres, 45290 Nogent-sur-Vernisson, France \\ ${ }^{\mathrm{b}}$ Biotope Centre Bourgogne, 125-127, Faubourg Bannier, 45000 Orléans, France \\ ${ }^{\mathrm{c}}$ DYNAFOR, INRA, Université de Toulouse, 31326 Castanet-Tolosan Cedex, France
}

\begin{abstract}
Increasing ungulate populations have been considered to drive changes in woodland bird communities in temperate and boreal forests. Ungulates may negatively affect understory-dependent woodland birds either directly or indirectly. For instance ungulates may prey on nests, or they may reduce the availability of nesting sites, foraging resources or cover for understory-dependent bird species.

We conducted ungulate pressure, vegetation and bird surveys on 95 plots, in 19 mature forest stands ( 9 fenced and 10 unfenced properties) located in the Sologne region (France). In such private forests, ungulate population densities are highly variable; we were therefore able to explore the effects of varying red deer (Cervus elaphus) browsing and wild boar (Sus scrofa) rooting intensity on bird communities. Bayesian Binomial mixture models indicated that ground-nesting birds were more abundant in forests with high observed wild boar rooting intensity.

Generally, increasing deer browsing pressure did not have any negative effect on woodland birds in mature forest stands with a developed canopy, and did not result in lower shrub cover. Most previous studies documenting a negative effect of browsing on birds focused on young forest stands where overstory vegetation was scarce. Our results suggest that the impact of ungulate pressure on forest birds may decrease with forest stand age.
\end{abstract}

\section{Zusammenfassung}

Zunehmende Huftierpopulationen werden für Verursacher von Änderungen in Vogelgemeinschaften von gemäßigten und borealen Wäldern gehalten. Die Huftiere können unterholzabhängige Waldvögel direkt und indirekt negativ beeinflussen. Sie können Nester plündern oder die Verfügbarkeit von Nistplätzen, Nahrung oder Deckung reduzieren. Wir führten Erhebungen zur Belastung durch Huftiere, zur Vegetation und zu den Vögeln auf 95 Probestellen in 19 reifen Wäldern (9 davon eingezäunt) in der Sologne-Region (Frankreich) durch. In solchen privaten Wäldern sind die Siedlungsdichten der Huftiere sehr variabel. Wir konnten deshalb die Effekte von unterschiedlichen Intensitäten der Beweidung durch Rothirsche (Cervus elaphus) und der Wühltätigkeit von Wildschweinen (Sus scrofa) auf die Vogelgemeinschaften untersuchen. Bayessche binomiale gemischte Modelle zeigten, dass die Abundanz der Bodenbrüter in Wäldern mit hoher Wühlintensität von Wildschweinen höher war.

\footnotetext{
*Corresponding author. Tel.: +3302389565 39; fax: +330238950359.

E-mail address: marie.baltzinger@irstea.fr (M. Baltzinger).
} 
Allgemein hatte zunehmende Beweidungsintensität durch Rotwild keine negativen Effekte auf die Waldvögel dieser reifen Waldbestände mit einer entwickelten Kronenschicht und führte nicht zu einer geringeren Unterwuchsbedeckung. Die meisten früheren Untersuchungen, die einen negativen Einfluss der Beweidung auf die Vögel feststellten, konzentrierten sich auf junge Waldbestände mit einem spärlichen Kronendach. Unsere Ergebnisse legen nahe, dass der Einfluss der Huftiere auf die Waldvögel mit zunehmendem Bestandsalter abnehmen könnte.

Keywords: Cascading effects; Game population management; Red deer; Wild boar; Woodland birds

\section{Introduction}

Since the last century, wild ungulate populations have increased spectacularly in many temperate and boreal forests. This dramatic spread of ungulate populations has been counted among the main drivers of global environmental change (Auer \& Martin 2013). Viable populations of large herbivores require large areas of land, and their browsing profoundly affects plant communities (Wallis De Vries 1995; Rooney \& Waller 2003). Beside their direct effect on plant communities, wild boar and deer may have such a widespread impact on vegetation that they can indirectly affect the whole ecosystem functioning (Côté, Rooney, Tremblay, Dussault, \& Waller 2004; Genov \& Massei 2004; Bressette, Beck, \& Beauchamp 2012). Deer and wild boar are thus considered keystone species in forested ecosystems (Waller \& Alverson 1997).

In particular, increasing ungulate populations have been considered a strong driver of change in forest bird communities, especially because understory-dependent birds may be threatened (Schley \& Roper 2003; Holt, Fuller, \& Dolman 2014; Newson, Johnston, Renwick, Baillie, \& Fuller 2012). Ungulates negatively affect bird communities either directly by wild boar preying on nests, nestlings or adult birds (Schley \& Roper 2003), or indirectly by modifying understory plant species composition and structure through wild boar rooting or deer browsing (Genov \& Massei 2004; Heinken, Schmidt, von Oheimb, Kriebitzsch, \& Ellenberg 2006; Boulanger et al., 2009). The so-called cascading effect hypothesis assumes that modification of the understory structure may reduce habitat quality for low-nesting birds, and decrease food availability for low-foraging insectivorous birds (Bressette et al. 2012; Teichman, Nielsen, \& Roland 2013). It has often been suggested in the literature that the lower in the vegetation the bird species forage or nest, the more they would be threatened under high ungulate pressure (Holt, Fuller, \& Dolman 2011; Newson et al. 2012; Holt et al. 2014). However, most of these studies considered the woodland understory layer as a whole, and combined shrub-dependent, grass-dependent and bareground-dependent bird species into the same bird guild (Holt et al. 2011, 2014; Fonderflick, Besnard, \& Martin 2013). In addition, authors have often mixed information about species requirements for nesting and for foraging in order to classify bird species as understory-dependent (Allombert, Gaston, \&
Martin 2005; Teichman et al. 2013). Ungulates may induce a shift from shrub to grass cover in the understory and they have been said to reduce habitat quality for some shrub-dependent woodland birds (Genov \& Massei 2004; Holt et al. 2011). However, ground-foraging bird species could benefit from an increase in bare soil areas (Schaub et al. 2010). Groundnesting and ground-foraging bird species may also suffer higher predation risk in patches with higher vegetation layers (Low, Arlt, Eggers, \& Pärt 2010). Understory-dependent bird species may thus respond in very different ways to increasing deer (Tymkiw, Bowman, \& Shriver 2013) and wild boar (Barrios-Garcia \& Ballari 2012) population densities.

Fencing is a fast spreading practice worldwide, especially as a wild game management tool (Somers \& Hayward 2011). As an experimental tool, fencing has been used either to exclude ungulates from fenced study sites (Holt et al. 2011, 2014), or to vary ungulate population densities inside fenced lots DeCalesta (1994). However, artificially high deer browsing intensities are likely to occur when the experimental enclosures are smaller than estimated deer home ranges (Tymkiw et al. 2013). To overcome such limitations, we studied how the actually encountered ungulate population densities may affect forest bird communities in nine fenced and ten unfenced forests in the French Sologne region. In this area, forest and game management practices vary widely depending on the owners' wishes and objectives; fences are often erected in order to maintain high game population densities within fenced lots. Deer browsing and wild boar rooting intensity vary as a result of the varying management practices: this quasi-experimental design allowed us to study how man-induced ungulate pressure may affect forest bird communities. We investigated the validity of a three-stepcascading-effect hypothesis compliant with deer-woodland bird interactions, as frequently described in the published literature (Allombert et al. 2005; Holt, Fuller, \& Dolman 2010). Firstly, we tested whether fencing resulted in higher deer browsing and wild boar rooting intensity inside fenced lots as compared to unfenced control forests (our first hypothesis). Secondly, we tested whether the understory vegetation layer varied according to varying ungulate pressure (our second hypothesis). Thirdly, we tested whether woodland bird communities - especially understory-dependent species were affected by ungulate pressure and modifications in the understory vegetation layer (our third hypothesis). 


\section{Materials and methods}

\section{Study area}

The study area was located in the Sologne Natural Region in the center of France. Sologne is characterized by its high forest cover, flat topography and poor clay/sand soils. Forest is rather open with low tree densities, and high light availability. Deciduous represent approximately $77 \%$ of the forest cover (Quercus robur: 39\%, Quercus petraea: 14\%, Betula pendula: $9 \%$ ); among the conifers, Pinus sylvestris is the most frequent species (13\%). Red deer (Cervus elaphus) and wild boar (Sus scrofa) populations have drastically increased during the past 40 years throughout the region. In 2011, for the whole Sologne region, hunting bags for red deer and wild boar respectively averaged 1.23 and 7.92 individuals per $\mathrm{km}^{2}$ of forested area (ONCFS 2012). This means that red deer and wild boar populations in Sologne in 2011 were among the highest red deer and wild boar populations ever recorded in France since 1995 (Boulanger 2010).

A noticeably rapid spread of private fences has occurred throughout the area. From a census of fences bordering roads in 145,000 ha out of the 500,000 ha of the Sologne Region, Froissart (2011) estimated that the area was crossed by more than $670 \mathrm{~km}$ of fences (Fig. 1).

\section{Study sites}

We restricted our study sites to properties of more than 100 ha where forest was the dominant land use (60-100\%) and, when the property was enclosed, the fenced area was at least 100 ha. We contacted private land owners and finally obtained permission to carry out field observations on nine fenced and ten unfenced properties.

Five plots per property were sampled (see details below). Sampled forests were representative of the forests occurring in Sologne. $Q$. robur was the main deciduous species and $P$. sylvestris the main conifer. B. pendula, Castanea sativa and Carpinus betulus also occurred as secondary species in mixed stands. The sampled forests were rather open, as expressed by the mean basal area $\left(18.6 \pm 7.4 \mathrm{~m}^{2}\right)$. As a result, the understory cover was quite well developed, with Ericaceae (mainly Calluna vulgaris) covering on average $6.3 \%$ of the sampled plots, ferns $5.7 \%$ and shrubs other than heather, $15.0 \%$ (Rubus fruticosus agg., Cytisus scoparius, Lonicera periclymenum, Prunus spinosa, Crataegus spp.).

\section{Sampling procedure within study sites}

Five $70 \mathrm{~m}$-radius plots per property were sampled, in mature forest stands (Fig. 2). We built a factorial design which crosses the 'fenced/unfenced' variable with the 'mainly broadleaf/mainly coniferous' variable because some woodland bird species and ungulates are known to display tree-species preferences (Donald, Fuller, Evans, \& Gough 1998; Heinze et al. 2011; Hewson, Austin, Gough, \& Fuller 2011). We considered a stand to be 'coniferous' if more than $50 \%$ of its basal area was composed of coniferous trees; the remaining stands were classed as 'broadleaved'. A field visit was made before final selection to insure that the plots were not situated in recently harvested forest stands or closer than $50 \mathrm{~m}$ to forest edges.

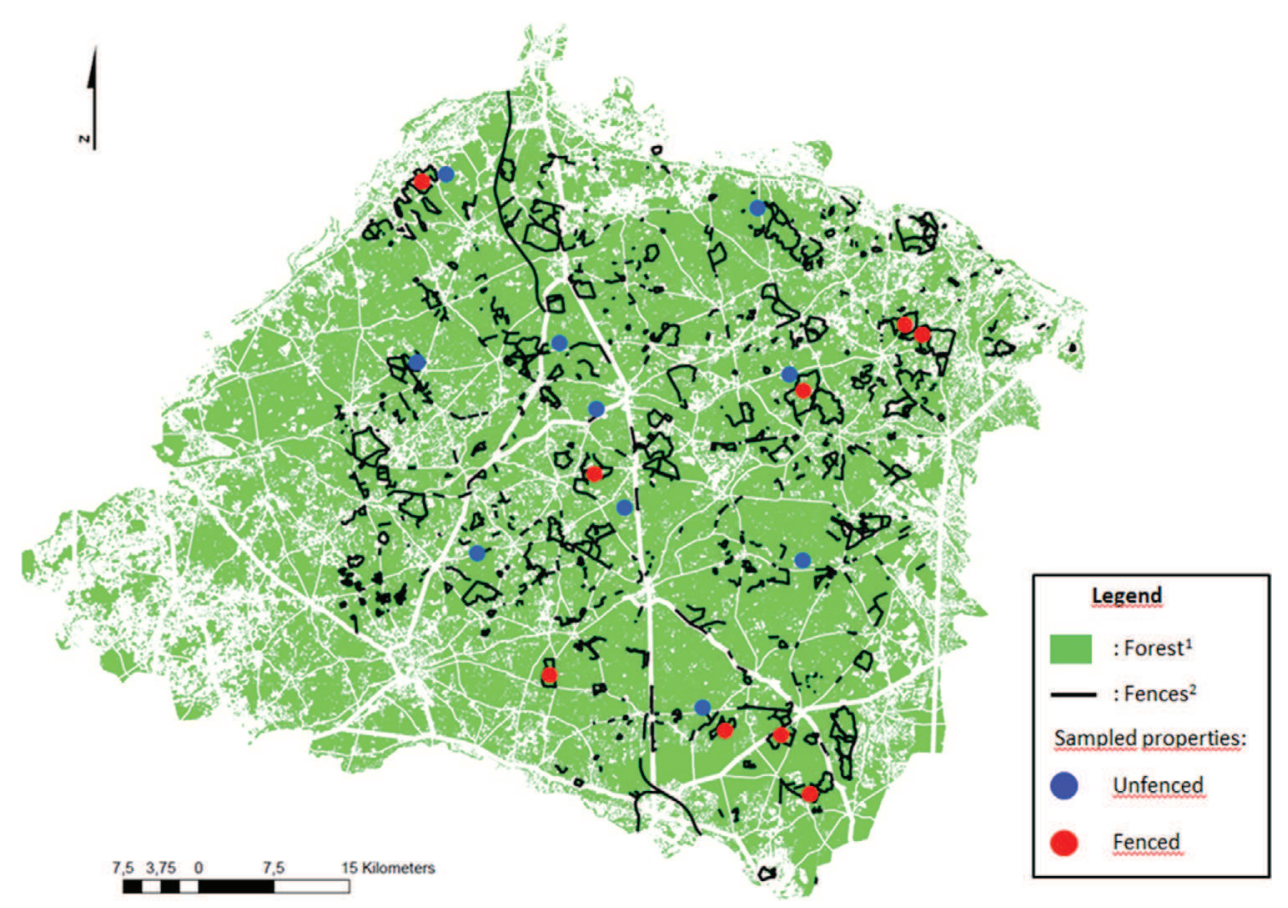

Fig. 1. Map of the Sologne Natural region and study sites. (1) Forest as defined by the French Forest Inventory (http://inventaire-forestier.ign.fr/spip/). (2) Fences as mapped by Froissart (2011). 


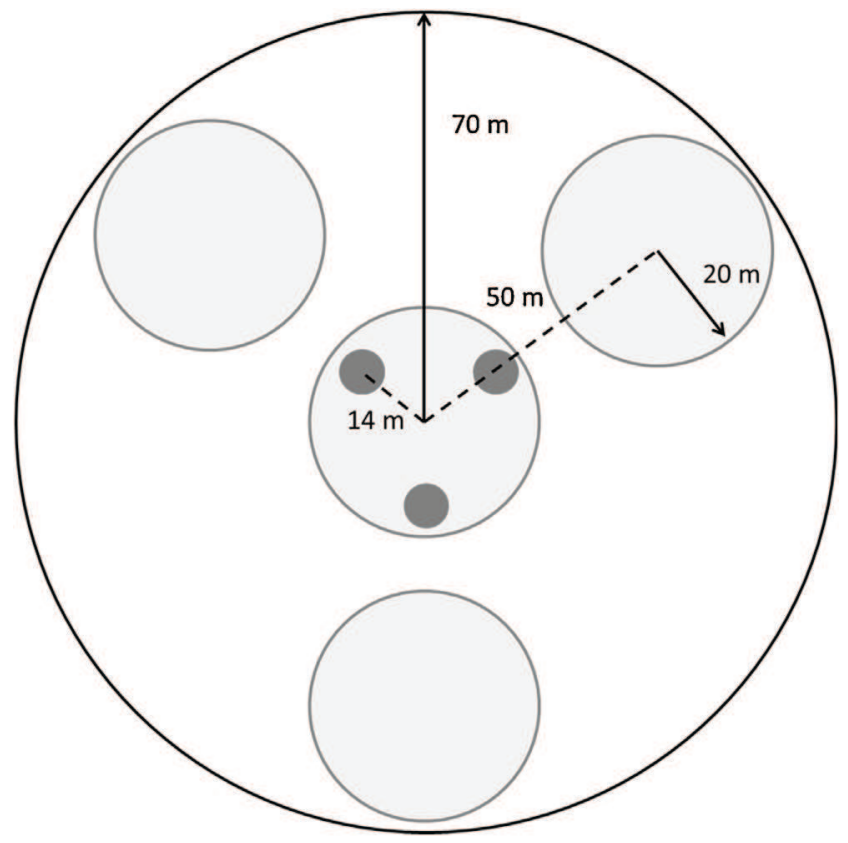

Fig. 2. Birds, vegetation and ungulate density survey. Vegetation cover and wild boar rooting area were recorded on four $20 \mathrm{~m}$-radius subplots (in light grey). Deer browsing pressure index was recorded on three $40 \mathrm{~m}^{2}$ plots (in dark grey). Point counts were conducted at the $70 \mathrm{~m}$ radius plot scale (outer circle, see text).

\section{Ungulate pressure and vegetation surveys}

Deer browsing pressure was quantified as described in Morellet and Guibert (1999) by comparing forage use and availability. This method focuses on winter browse (woody and semi-woody vegetation) accessible to deer $(0-2 \mathrm{~m})$ in late winter (March) before the start of the growing season. Browsing pressure indices $B_{. j}$ were estimated on three $40 \mathrm{~m}^{2}$ circular subplots, each situated at a distance of $14 \mathrm{~m}$ from the center of the study plot (Fig. 2), according to the formula:

$B_{. j}=\frac{\sum_{i=1}^{n} c_{i j} * b_{i j}}{\sum_{i=1}^{n} c_{i j}}$

where $c_{i j}$ is the cover of plant species $i$ at subplot $j$ (the horizontal projection of shoots, twigs and branches); $b_{i j}$ is the percentage of available shoots of plant species $i$ at plot $j$ actually browsed. Forage use $\left(b_{i j}\right)$ and availability $\left(c_{i j}\right)$ were visually estimated according to a six-level discrete scale $(0-1 \%, 1-5 \%, 5-20 \%, 20-50 \%, 50-75 \%, 75-100 \%)$, then converted to mid-point values for statistical analyses.

We used a ten-level discrete scale to visually estimate the percentage of soil disturbed by wild boar on four $20 \mathrm{~m}$-radius subplots (Fig. 2).

Ultimately, we computed for each sampled property a mean browsing pressure index and a mean wild-boar rooting index, as reliable assessments of ungulate pressure at this home range scale (Morellet, Champely, Gaillard, Ballon, \& Boscardin 2001).
On each plot, we used a ten-level discrete scale to visually estimate the horizontal cover percentage of grass, heather, shrubs and ferns separately in four $20 \mathrm{~m}$-radius circular subplots (Fig. 2). We then averaged grass, shrub, heather and fern cover at the plot scale.

\section{Bird surveys}

Five observers conducted breeding bird censuses in 2013 and 2014. Each 70 m-radius plot (Fig. 2) was sampled twice during at least one breeding season by the same observer (first survey period centered on April 23; second survey period centered on June 1). Ten-minute point counts were conducted: each time a bird was heard or seen within a $70 \mathrm{~m}$-radius plot (measured using a laser telemeter), the observer first assessed whether he/she was likely to have already recorded the bird at that plot on that same survey date; only if that was not the case, was the bird recorded and its species registered. Surveys were completed before 11:30 am in calm weather conditions.

In addition, 37 of the 95 plots were sampled by more than one observer; 30 out of the 37 double-observer plots were sampled in both 2013 and 2014.

\section{Data analysis}

First of all, we used frequentist linear regressions to test whether mean browsing pressure and mean wild boar rooting at the property scale differed between fenced and unfenced properties. We then used mixed models with a random property effect (R Development Core Team, 2015, plus lme4 package) to test whether the fencing variable and ungulate pressure indices recorded at the property scale significantly affected the vegetation variables recorded at the plot scale. We also performed an RLQ analysis (ade4 package, Dray et al. 2013) to identify the main patterns of co-variation between the sampled bird communities, ungulate pressure and vegetation variables (referred to as environmental variables or "R" in the RLQ analysis) and the bird species traits ("Q" in the RLQ analysis). Finally, we developed Bayesian binomial mixed models (Royle 2004; Kéry \& Schaub 2011) to test the significance of these co-variations between ungulate pressure, environmental variables and bird species traits.

\section{Bird species traits}

We selected four life-history traits for forest birds likely to underlie a bird's response to varying ungulate pressures (see Appendix A: Table 2) from the literature (BWPi 2.0.2 http://www.birdguides.com/bwpi/default.asp):

(1) Preferred nesting height: we considered ground-, shruband canopy-nesting bird species separately.

(2) Preferred foraging resource: we considered dead-woodforaging, foliage-only foraging, ground-and-foliageforaging, and possible-outside-foraging birds (large 
birds whose foraging area was likely to extend beyond the $70 \mathrm{~m}$-radius sample plot) separately.

(3) Mean weight and (4) mean wing length were used as proxies for bird size and thus bird feeding territory size (Schoener 1971).

\section{RLQ analysis}

We performed an RLQ analysis (Dray et al. 2013) in order to identify the main traits involved in bird responses to varying ungulate pressure. Each plot contributed only once in the RLQ analysis: we first computed the highest recorded abundance for each year/observer combination. When plots were surveyed by more than one observer and/or for more than one breeding season, we averaged these estimated abundances (rounded to the nearest integer).

\section{Bayesian binomial mixture models}

On each plot and for each trait-based guild of bird species, we jointly estimated its local abundance and the detection probability for the guild integrated over observer and year, using Bayesian binomial mixture modelling (Royle 2004; Kéry \& Schaub 2011). We also fitted models for individual bird species, when they were frequent enough. Bird abundance was modeled as following a Poisson distribution, and detection probability as following a Binomial distribution (see Appendix A3 for more details on model likelihood, priors, and initial values).

For each model, we ran three Markov chains (70,000 iterations each), discarded the first 30,000 and recorded the next 40,000 iterations. We visually and numerically checked the Markov chain convergence with the R-hat value (Kéry \& Schaub 2011). For each parameter of each model, we calculated the number of simulated zero, negative and positive values divided by the total number of simulated values; we used these ratios as statistical significance tests (Kéry \& Schaub 2011). Because the Deviance Information Criterion (DIC) cannot be calculated for Bayesian models with discrete latent nodes, we assessed our model fitness with posterior predictive checking (Kéry \& Schaub 2011): a $p$-value between 0.1 and 0.9 indicates that real data could plausibly have been generated by the model (see Appendix A3 for more details on how derived quantities were calculated and what parameters were monitored).

\section{Results}

\section{Main patterns of co-variation between environmental variables}

Forty-four bird species were recorded during 300 point counts made by five observers during two breeding seasons on the 95 survey plots. Mean deer browsing pressure was significantly higher inside fenced properties (Table 1). Mean deer browsing pressure and mean wild boar rooting at the property scale proved to be significantly and positively correlated (linear regression: $F$-value $=12.3, p$-value $=0.003$ ). Still, wild boar rooting was not significantly different inside fenced properties and in unfenced ones (Table 1). Grass cover was significantly higher on properties with a high mean deer browsing pressure (Fig. 3A - mixed linear model with random effect for property: model null deviance $=779.72$ with $3 \mathrm{df}$; model 1 deviance $=771.7$ with $4 \mathrm{df}$; Chi-square test $p$ value $=0.005$ ), but it did not co-vary with wild boar rooting. Finally, no vegetation variable except grass cover did co-vary with ungulate pressure indices, even though fern cover was significantly higher on fenced properties (Table 1 and Fig. 3). Neither basal area nor broadleaf ratio significantly differed according to the fencing treatment (Table 1).

\section{RLQ analysis}

The cross-covariance between traits and environmental variables was reasonably well represented by the first two axes of the RLQ (30\% and 18\% for axes 1 and 2, respectively). The variances in the environmental (Fig. 4A) and trait scores (Fig. 4B) were well preserved in the first two axes $(81 \%$, and $83 \%$ respectively). The first axis of the RLQ discriminated small bird species with small home ranges on the negative side (Trogoldytes troglodytes, Phyloscopus collybita) from large species with home ranges extending beyond the $70 \mathrm{~m}$ radius sampled plots on the positive side (Columba palumbus, Corvus corone) (Fig. 4C). Wild boar rooting also scored high on the first axis (Fig. 4A). The second axis discriminated ground-nesting species on the positive side (Anthus trivialis, Phylloscopus sibilatrix, Phylloscopus bonelli, Phylloscopus trochilus) from shrub-nesting species on the negative side (Sylvia atricapilla, P. collybita) (Fig. 4C). This second axis discriminated properties with high ungulate activity indices and high ground-nesting bird abundances from properties with low ungulate activity indices and high shrub-nesting bird abundances, as illustrated by the high scores of browsing pressure and wild boar rooting (Fig. 4A).

\section{Bayesian binomial mixture models for bird species abundance}

We built two sets of models: the "browsing pressure" family and the "wild boar rooting" family, to avoid problems of collinearity between both pressure indices. We retained the shrub and grass cover variables because the RLQ analysis indicated that they were good summaries of the low vegetation conditions in our dataset, and discarded the fern and heather cover (Fig. 4A). All models also included basal area and broadleaf ratio, as they are indicative of the canopy.

Model fit was reasonable except for the possible-outsideforaging guild, the ground-and-foliage-foraging guild and for the individual-species model "Fringilla coelebs" (FRICOE 
Table 1. Effect of the fencing on ungulate pressure, vegetation and birds. Browsing pressure and wild boar rooting were averaged at the property scale, whereas vegetation variables refer to the plot scale. Browsing pressure and wild boar rooting were fitted as Gaussian; vegetation variables were fitted as Gaussian with a random property effect and a fixed fencing effect. Bird's richness and abundances were fitted as Poisson counts, with property and point random effects and a fixed fencing effect. We compared the deviance of each model with the deviance of the corresponding null model (without the fixed fencing effect) with a Chi-square test.

\begin{tabular}{|c|c|c|c|c|c|}
\hline & \multicolumn{2}{|c|}{ Fenced properties } & \multicolumn{2}{|c|}{ Unfenced properties } & \multirow[t]{2}{*}{$p$-value of difference } \\
\hline & Mean & SE & Mean & SE & \\
\hline Species richness & 5.31 & 0.17 & 5.19 & 1.11 & 0.50 \\
\hline \multicolumn{6}{|l|}{ Bird abundances } \\
\hline All species & 6.01 & 0.19 & 5.82 & 0.20 & 0.44 \\
\hline Ground nesting & 0.71 & 0.08 & 0.42 & 0.05 & 0.21 \\
\hline Shrub nesting & 1.73 & 0.12 & 2.09 & 0.12 & 0.41 \\
\hline High nesting & 3.56 & 0.15 & 3.27 & 0.14 & 0.20 \\
\hline Ground/foliage foragers & 2.54 & 0.10 & 2.33 & 0.10 & 0.30 \\
\hline Foliage foragers & 2.89 & 0.15 & 2.96 & 0.13 & 0.86 \\
\hline Dead wood foragers & 0.37 & 0.05 & 0.30 & 0.04 & 0.31 \\
\hline Possible outside foragers & 0.20 & 0.04 & 0.20 & 0.04 & 0.66 \\
\hline Cyanistes caeruleus & 0.29 & 0.04 & 0.32 & 0.04 & 0.72 \\
\hline Erithacus rubecula & 0.55 & 0.05 & 0.52 & 0.05 & 0.82 \\
\hline Fringilla coelebs & 1.16 & 0.06 & 1.04 & 0.06 & 0.31 \\
\hline Sitta europaea & 0.25 & 0.04 & 0.23 & 0.03 & 0.73 \\
\hline Phylloscopus collybita & 0.32 & 0.05 & 0.50 & 0.05 & $0.05^{*}$ \\
\hline Parus major & 0.25 & 0.04 & 0.20 & 0.03 & 0.41 \\
\hline Sylvia atricapilla & 0.40 & 0.05 & 0.39 & 0.04 & 0.77 \\
\hline Troglodytes troglodytes & 0.33 & 0.05 & 0.43 & 0.04 & 0.27 \\
\hline \multicolumn{6}{|l|}{ Environmental variables } \\
\hline Browsing pressure & 28.1 & 4.57 & 12.8 & 0.04 & $0.02 *$ \\
\hline Wild boar rooting & 5.12 & 1.27 & 2.74 & 0.68 & 0.10 \\
\hline Grass cover & 16.61 & 2.45 & 9.20 & 1.87 & 0.07 \\
\hline Shrub cover & 13.00 & 2.71 & 16.70 & 2.70 & 0.42 \\
\hline Heather cover & 6.28 & 2.20 & 6.35 & 1.96 & 0.98 \\
\hline Fern cover & 2.17 & 0.90 & 8.90 & 2.28 & $0.01 *$ \\
\hline Broadleaf ratio & 0.69 & 0.06 & 0.60 & 0.06 & 0.31 \\
\hline Basal area & 18.10 & 1.11 & 19.12 & 1.06 & 0.48 \\
\hline
\end{tabular}

model, Table 2). Basically, this means that no explanatory variable consistently correlated with these guilds abundance (consistent with their low scores in the RLQ). Abundance of both ground-nesting and high-nesting guilds was greater in properties with high ungulate pressure. Higher ungulate pressure indices were never associated with a lower abundance of any bird guild. Species richness, total bird abundance and

(A) Grass cover

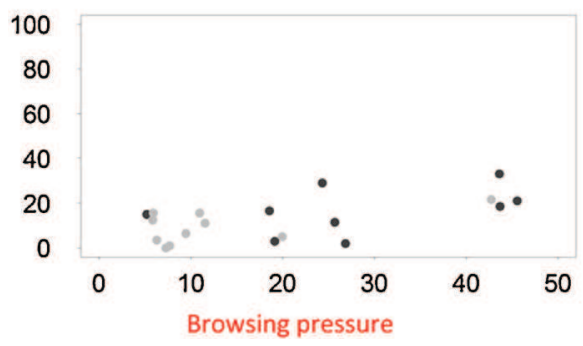

most bird guild abundance values (except for ground-nesting and high-nesting birds) were higher in plots with high shrub cover. Among shrub-nesting and foliage-foraging species, $S$. atricapilla, Troglodytes troglodytes and P. collybita were more abundant in plots with high shrub cover. The greater the grass cover, the higher the ground-nesting bird abundance. High-nesting and dead-wood-foraging birds were more
(B) Shrub cover

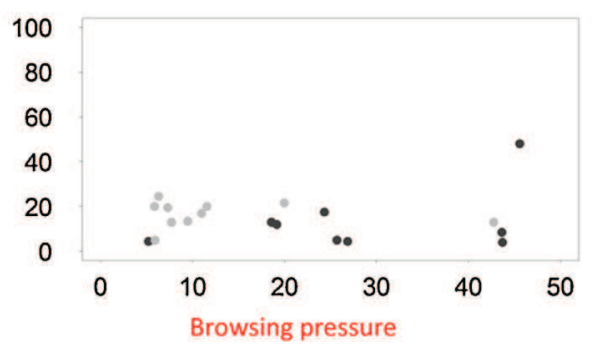

Fig. 3. Variation in the shrub and grass cover according to browsing pressure and fencing. Black dots: fenced properties; white dots: unfenced properties. (A) Grass cover. (B) Shrub Cover. Mixed models with a random property effect indicated that: (A) browsing pressure resulted in higher grass cover $(p$-value $=0.005)$; $(\mathrm{B})$ browsing pressure did not significantly affect shrub cover. 
(A)

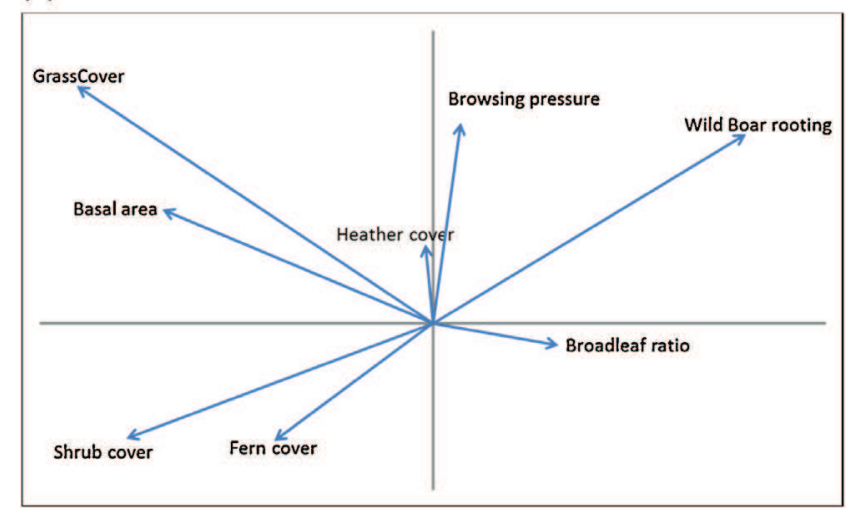

(B)

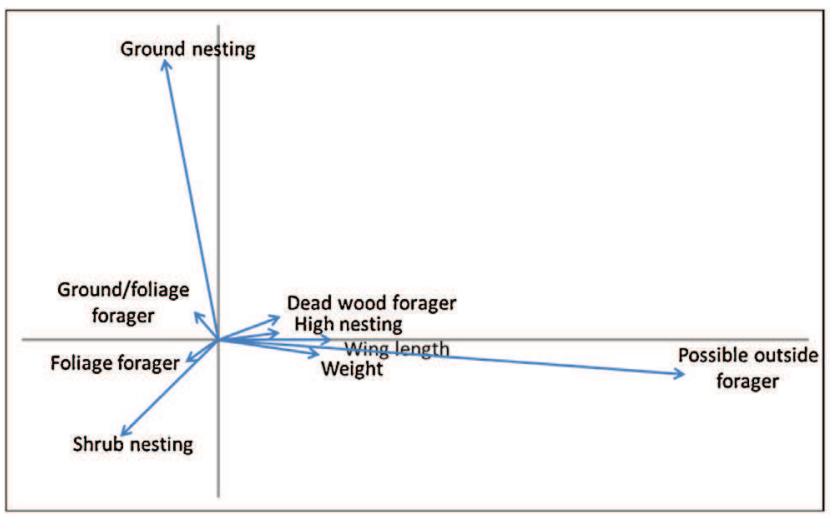

(C)

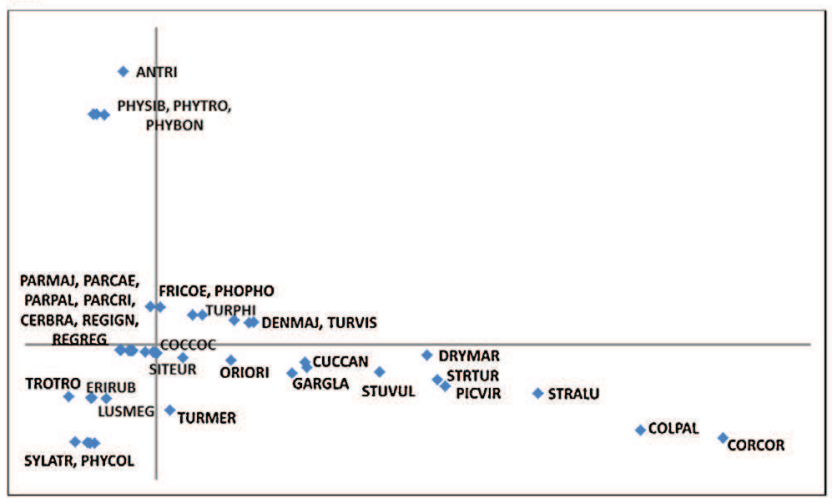

Fig. 4. Projections on the first two axes of the RLQ analysis. (A) Environmental variables. (B) Species traits. (C) Barycenter of most frequent bird species; species codes are listed in Appendix A: Table 2.

abundant in plots with a high broadleaf ratio. Among high-nesting birds, Cyanistes caeruleus, Parus major and Sitta europaea, showed the same preference for broadleaves.

\section{Discussion}

Many studies documented a shift from shrub to grass cover in highly browsed forests (Holt et al. 2011; Teichman et al.
2013). The red deer, as an intermediate mixed feeder, is known to rely on grazing for about $30 \%$ of its year-round diet (Gebert and Verheyden-Tixier 2008) and on browsing for the other $70 \%$. Repeatedly grazing the same patches induces vigorous re-sprouting of grazing-tolerant grasses (appearance of a "grazing lawn"), as has long been documented (Díaz et al. 2007; Skarpe \& Hester 2008). On the other hand, increasing ungulate browsing usually results in decreasing shrub cover (Allombert et al. 2005; Holt et al. 2011), though repeated browsing may sometimes lead to the formation of a low vegetation layer characterized by a high production of the preferred browse, forming what might be called a "browsing lawn" analogous to a "grazing lawn" (Skarpe \& Hester 2008; Cromsigt \& Kuijper 2011). Boulanger (2010) investigated the effect of varying ungulate population densities on the development of the shrub cover on 82 plots spread over the whole French territory in 1995, 2000 and 2005. He observed that shrub cover was little or no different under a wide range of ungulate population densities, which would mean that even the highest ungulate population densities encountered in his plots represented only moderately high herbivory pressure. It is noteworthy that the highest ungulate population densities he investigated were similar to the densities in our study area (ONCFS 2012). Ungulate herbivory effect on shrub cover is in fact likely to vary according to ungulate species, population densities, forest structure and understory composition (Chase, Leibold, \& Simms 2000; Fuller 2013). In the mature forests we studied, higher browsing pressure did not result in a lower shrub cover. We therefore consider that our result is in line with Boulanger (2010), whose study was undertaken in quite similar conditions. However, we did observe a significant positive effect of shrub cover on abundance for most bird guilds, on total bird species richness and on total bird abundance.

Ungulate pressure indices were higher inside fenced properties; grass cover was greater in properties with high browsing pressure. This is consistent with our first hypothesis that higher ungulate pressure occurs inside fenced lots compared to unfenced controls, as well as with our second hypothesis that higher ungulate pressure results in significant modifications in the understory vegetation. However, it is not possible to ascertain that the fencing was responsible for the higher ungulate pressure we observed inside fenced properties, because several other practices are usually associated with fencing (for instance, unauthorized supplementary feeding). The greater the grass cover, the higher the ground-nesting bird abundance. This result is consistent with our third hypothesis that the understory vegetation layer, as modified by ungulates, affects nesting resource availability for woodland birds. Interestingly, the increase in grass cover did not result in more foraging opportunities: abundances of F. coelebs, Erithacus rubecula, and ground-and-foliageforaging bird species in general, did not increase in plots with greater grass cover. Yet, other authors have observed that ground-foraging birds may select patches with more bare ground (Schaub et al. 2010) and may be more likely to 
Table 2. Main results of the Bayesian binomial mixture models for bird species abundance.

\begin{tabular}{|c|c|c|c|c|c|c|c|c|c|}
\hline & \multicolumn{9}{|l|}{ Abundance } \\
\hline & $\begin{array}{l}\text { Species } \\
\text { richness }\end{array}$ & All species & $\begin{array}{l}\text { Ground } \\
\text { nesting }\end{array}$ & $\begin{array}{l}\text { Shrub } \\
\text { nesting }\end{array}$ & $\begin{array}{l}\text { High } \\
\text { nesting }\end{array}$ & $\begin{array}{l}\text { Foliage } \\
\text { foraging }\end{array}$ & $\begin{array}{l}\text { Ground and } \\
\text { foliage for. }\end{array}$ & $\begin{array}{l}\text { Dead wood } \\
\text { for. }\end{array}$ & $\begin{array}{l}\text { Possible } \\
\text { outside for. }\end{array}$ \\
\hline \multicolumn{10}{|l|}{ (a) } \\
\hline Browsing pressure & NS & $\begin{array}{l}\mathbf{0 . 0 0 6} \\
(0.003)^{*}\end{array}$ & $\begin{array}{l}\mathbf{0 . 0 2 0} \\
(0.009)^{*}\end{array}$ & NS & $\begin{array}{l}\mathbf{0 . 0 0 6} \\
(0.004)^{*}\end{array}$ & NS & NS & NS & NS \\
\hline Grass cover & NS & NS & $\begin{array}{l}\mathbf{0 . 0 1 4} \\
(0.007)^{*}\end{array}$ & NS & NS & NS & NS & NS & NS \\
\hline Shrub cover & $\begin{array}{l}\mathbf{0 . 0 0 5} \\
(0.002)^{* *}\end{array}$ & $\begin{array}{l}\mathbf{0 . 0 0 5} \\
(0.002)^{* *}\end{array}$ & NS & $\begin{array}{l}\mathbf{0 . 0 1 1} \\
(0.003)^{* *}\end{array}$ & NS & $\begin{array}{l}\mathbf{0 . 0 0 7} \\
(0.002)^{*} *\end{array}$ & NS & NS & NS \\
\hline Broadleaf Ratio & NS & NS & NS & NS & $\begin{array}{l}\mathbf{0 . 2 6 6} \\
(0.123)^{*}\end{array}$ & NS & NS & $\begin{array}{l}\mathbf{0 . 6 2 0} \\
(0.338)^{*}\end{array}$ & NS \\
\hline Basal Area & NS & NS & NS & NS & NS & NS & NS & NS & NS \\
\hline Detect. Proba. & 0.33 & 0.26 & 0.46 & 0.38 & 0.29 & 0.36 & 0.44 & 0.09 & 0.21 \\
\hline Rho & 0.01 & 0.01 & 0.04 & 0.02 & 0.01 & 0.02 & 0.01 & 0.01 & 0.33 \\
\hline Fit & 164.47 & 189.19 & 57.32 & 135.16 & 166.77 & 152.71 & 113.27 & 81.06 & 50.07 \\
\hline FitNew & 180.71 & 202.16 & 59.61 & 137.26 & 182.46 & 158.68 & 136.19 & 98.47 & 50.46 \\
\hline$p$-Value of the model & $0.22 \dagger$ & $0.29 \dagger$ & $0.36 \dagger$ & $0.45 \dagger$ & $0.22 \dagger$ & $0.38 \dagger$ & 0.06 & $0.11 \dagger$ & 0.03 \\
\hline \multicolumn{10}{|l|}{ (b) } \\
\hline Wild boar rooting & NS & NS & $\begin{array}{l}\mathbf{0 . 0 7 7} \\
(0.038)^{*}\end{array}$ & NS & $\begin{array}{l}\mathbf{0 . 0 2 7} \\
(0.015)^{*}\end{array}$ & NS & NS & NS & NS \\
\hline Grass cover & NS & NS & $\begin{array}{l}\mathbf{0 . 0 1 6} \\
(0.007)^{*}\end{array}$ & NS & NS & NS & NS & NS & NS \\
\hline Shrub cover & $\begin{array}{l}\mathbf{0 . 0 0 5} \\
(0.002)^{* *}\end{array}$ & $\begin{array}{l}\mathbf{0 . 0 0 5} \\
(0.002) * *\end{array}$ & NS & $\begin{array}{l}\mathbf{0 . 0 1 0} \\
(0.003)^{* *}\end{array}$ & NS & $\begin{array}{l}\mathbf{0 . 0 0 7} \\
(0.002)^{* *}\end{array}$ & NS & NS & NS \\
\hline Broadleaf Ratio & NS & NS & NS & NS & $\begin{array}{l}\mathbf{0 . 2 8 8} \\
(0.123)^{* *}\end{array}$ & NS & NS & $\begin{array}{l}\mathbf{0 . 6 5 1} \\
(0.333)^{*}\end{array}$ & NS \\
\hline Basal Area & NS & NS & NS & NS & NS & NS & NS & NS & NS \\
\hline Detect. Proba. & 0.35 & 0.29 & 0.45 & 0.37 & 0.29 & 0.34 & 0.45 & 0.08 & 0.21 \\
\hline Rho & 0.01 & 0.01 & 0.05 & 0.02 & 0.01 & 0.01 & 0.01 & 0.01 & 0.33 \\
\hline Fit & 162.59 & 184.49 & 57.24 & 135.87 & 166.37 & 157.36 & 112.58 & 81.06 & 50.18 \\
\hline FitNew & 177.42 & 196.19 & 59.67 & 139.13 & 181.93 & 164.84 & 133.31 & 98.64 & 50.51 \\
\hline$p$-Value of the model & $0.24 \dagger$ & $0.30 \dagger$ & $0.35 \dagger$ & $0.42 \dagger$ & $0.22 \dagger$ & $0.35 \dagger$ & 0.07 & $0.12 \dagger$ & 0.03 \\
\hline
\end{tabular}


Table 2. (Continued)

\begin{tabular}{|c|c|c|c|c|c|c|c|c|}
\hline & \multicolumn{8}{|c|}{ Abundance } \\
\hline & ERIRUB & FRICOE & PHYCOL & SYLATR & TROTRO & SITEUR & PARMAJ & PARCAE \\
\hline \multicolumn{9}{|l|}{ (a) } \\
\hline Browsing pressure & NS & NS & NS & NS & NS & NS & NS & NS \\
\hline Grass cover & NS & NS & NS & NS & NS & NS & NS & NS \\
\hline Shrub cover & NS & NS & $\begin{array}{l}\mathbf{0 . 0 1 4} \\
(0.005)^{* *}\end{array}$ & $\begin{array}{l}\mathbf{0 . 0 1 7} \\
(0.006) * *\end{array}$ & $\begin{array}{l}\mathbf{0 . 0 1 6} \\
(0.005)^{* *}\end{array}$ & NS & NS & NS \\
\hline Broadleaf Ratio & NS & NS & NS & NS & NS & $\begin{array}{l}\mathbf{0 . 9 1 2} \\
(0.481)^{*}\end{array}$ & $\begin{array}{l}\mathbf{0 . 9 7 1} \\
(0.500)^{*}\end{array}$ & $\begin{array}{l}\mathbf{1 . 4 7 7} \\
(0.467)^{* *}\end{array}$ \\
\hline Basal Area & NS & NS & NS & NS & $\begin{array}{l}\mathbf{0 . 0 3 9} \\
(0.018)^{*}\end{array}$ & NS & NS & NS \\
\hline Detect. Proba. & 0.47 & 0.60 & 0.34 & 0.40 & 0.28 & 0.19 & 0.22 & 0.33 \\
\hline Rho & 0.04 & 0.03 & 0.04 & 0.04 & 0.02 & 0.03 & 0.02 & 0.03 \\
\hline Fit & 60.44 & 62.75 & 66.36 & 54.04 & 64.64 & 56.49 & 50.91 & 50.43 \\
\hline FitNew & 64.22 & 72.78 & 69.18 & 58.66 & 73.31 & 61.98 & 56.62 & 55.19 \\
\hline$p$-Value of the model & $0.28 \dagger$ & 0.06 & $0.37 \dagger$ & $0.22 \dagger$ & $0.15 \dagger$ & $0.30 \dagger$ & $0.24 \dagger$ & $0.25 \dagger$ \\
\hline \multicolumn{9}{|l|}{ (b) } \\
\hline Wild boar rooting & NS & NS & NS & NS & NS & NS & NS & NS \\
\hline Grass cover & NS & NS & NS & NS & NS & NS & NS & NS \\
\hline Shrub cover & NS & NS & $\begin{array}{l}\mathbf{0 . 0 1 3} \\
(0.005)^{* *}\end{array}$ & $\begin{array}{l}\mathbf{0 . 0 1 6} \\
(0.006)^{* *}\end{array}$ & $\begin{array}{l}\mathbf{0 . 0 1 6} \\
(0.005) * *\end{array}$ & NS & NS & $\begin{array}{l}\mathbf{0 . 0 1 1} \\
(0.007)^{*}\end{array}$ \\
\hline Broadleaf Ratio & NS & NS & NS & NS & NS & $\begin{array}{l}\mathbf{0 . 9 5 0} \\
(0.484)^{*}\end{array}$ & $\begin{array}{l}\mathbf{1 . 0 2 9} \\
(0.502)^{*}\end{array}$ & $\begin{array}{l}\mathbf{1 . 4 8 9} \\
(0.461)^{* *}\end{array}$ \\
\hline Basal Area & NS & NS & NS & NS & $\begin{array}{l}\mathbf{0 . 0 3 7} \\
(0.018)^{*}\end{array}$ & NS & NS & NS \\
\hline Detect. Proba. & 0.46 & 0.60 & 0.33 & 0.40 & 0.30 & 0.18 & 0.22 & 0.34 \\
\hline Rho & 0.04 & 0.02 & 0.04 & 0.03 & 0.03 & 0.02 & 0.03 & 0.04 \\
\hline Fit & 60.94 & 63.68 & 67.26 & 54.54 & 62.84 & 57.17 & 50.51 & 49.31 \\
\hline FitNew & 65.24 & 73.90 & 70.41 & 59.30 & 70.78 & 63.11 & 56.08 & 53.82 \\
\hline$p$-Value of the model & $0.26 \dagger$ & 0.06 & $0.36 \dagger$ & $0.22 \dagger$ & $0.16 \dagger$ & $0.28 \dagger$ & $0.24 \dagger$ & $0.25 \dagger$ \\
\hline
\end{tabular}

Figures in bold indicate a regression coefficient significantly different from zero at 5\% (*) and 1\% (**) confidence intervals, standard deviation for significant regression coefficients are given in parentheses. NS indicates regression coefficients not significantly different from zero. Model fitness was assessed via posterior predictive checking (Kéry \& Schaub 2011). † indicates models which likely lay behind the observed datasets - note that a $p$-value between 0.1 and 0.9 means that real data could plausibly have been generated by the model (Kéry \& Schaub 2011). Detect. Proba: mean detection probability. rho: correlation coefficient for the detection probabilities (Martin et al. 2011). fit: Chi ${ }^{2}$ discrepancy measure of fit for real data given the model. fitNew: Chi ${ }^{2}$ discrepancy measure of fit for simulated data given the model (Kéry \& Schaub 2011). $p$-Value of the model: probability of the data given the model (posterior predictive checking Kéry \& Schaub 2011). A $p$-value between 0.1 and 0.9 indicates that real data could plausibly have been generated by the model. The model script is given in Appendix A: 3. ERIRUB: Erithacus rubecula, FRICOE: Fringilla coelebs, PHYCOL: Phylloscopus collybita, SYLATR: Sylvia atricapilla, TROTRO: Troglodytes troglodytes, SITEUR: Sitta europaea, PARMAJ: Parus major, PARCAE: Cyanistes caeruleus. 
survive in patches where the grass layer is lower (Low et al. 2010). Still these studies recorded bare ground proportion, grass height and bird behavior and survival with much greater precision than we did; this may explain why we did not find any such positive effect.

Ground-nesting birds were more abundant in the properties with high ungulate pressure indices, whereas the reverse situation has frequently been observed (Holt et al. 2010, 2014). This may in part stem from our definition of the groundnesting guild which retained only true ground-nesters and deliberately excluded birds which nest in the low vegetation layer. Indeed, most previous studies on the topic usually combined strictly ground-nesting birds and those nesting in the lower vegetation layer into the same guild (Holt et al. 2011, 2014; Fonderflick et al. 2013). Most of the ground-nesting bird species we considered, such as $P$. sibilatrix and A. trivialis, are known to prefer open forests with little understory vegetation and to be more abundant in heavily grazed forest stands (Mitchell \& Kirby 1990; Fuller 2001). Working outside of Europe, DeCalesta (1994) and Tymkiw et al. (2013), did not find any effect of varying deer densities on either species richness or abundance of ground-nesting birds.

Ungulates are usually considered to be ground nest predators, especially wild boar through their rooting activities (Schley \& Roper 2003; Genov \& Massei 2004). Yet, few studies have quantitatively estimated wild boar predation rate on nests (but see Svobodová, Koubová, Mrštný, Albrecht, \& Kreisinger 2011). In addition, wild boar rooting is just as likely to dig out small mammal dens as to dig out bird nests. This could reduce predation on bird nests (Schley \& Roper 2003), because several other forest-dwelling species besides wild boar - birds and small mammals, for instance - are known to feed on ground nests (Söderström, Pärt, \& Rydén 1998; Svobodová et al. 2011). Consequently, one would expect complex interactions among nest predators to be involved in the net effect of wild boar population densities on ground nest predation. Wild boar rooting may even increase habitat attractiveness to ground-nesting birds requiring disturbed habitats (Barrios-Garcia \& Ballari 2012).

In any case, the point count method may not be the best suited to accurately investigate nest predation rates, in particular because point count sampling might not faithfully represent actual bird population densities. Indeed, male singing rates are known to vary according to pairing status, breeding density, food availability and nest predation risk (Toms, Schmiegelow, Hannon, \& Villard 2006; Robertson, Hutto, \& Fontaine 2010). In particular, unpaired males in marginal habitat may sing more frequently than paired males (Toms et al. 2006). In addition, the point count method is unsuited to detect non-singing females while ground nesting females are more likely to suffer predation than males (Low et al. 2010). More intensive bird population surveys are necessary in order to conclude on the effects of wild board rooting on ground nesting birds.

We did not observe any negative effect of ungulate pressure on the abundance of any of the bird guilds we considered.
Yet, increasing ungulate densities have overwhelmingly been seen as a threat to forest ecosystems, and to woodland birds (Allombert et al. 2005; Bressette et al. 2012; Newson et al. 2012). One possible explanation for this contradiction is that high ungulate densities may not be detrimental to all birds in all woodlands. For instance, DeCalesta (1994) and Tymkiw et al. (2013) observed that the abundance and richness of most woodland guilds were not significantly different under highly variable ungulate population densities and stand types.

Dead-wood-foraging species and high-nesting species particularly C. caeruleus, Parus major, and S. europaeawere more numerous in broadleaf-dominated stands. Tree canopy composition and structure are known to shape not only canopy-dependent bird species assemblages but the whole woodland bird community (Donald et al. 1998; Hewson et al. 2011). Even if herbivory may limit tree growth to browsing height in young regenerating stands, once trees have passed this threshold, the canopy can develop free of ungulate influence (Gerhardt, Arnold, Hackländer, \& Hochbichler 2013). This point is noteworthy because many authors who reported significant effects of high ungulate population densities on woodland bird communities were, in fact, working in very young stands (Holt et al. 2011, 2014).

\section{Conclusion}

According to our point count sampling protocol, high ungulate pressure did not result in lower foraging or nesting opportunities for understory-dependent birds. Before concluding that there is truly no negative impact of large ungulates on birds in our study area, more intensive bird population surveys including nest monitoring should be conducted to prove that places with high ungulate population densities have not become ecological traps.

\section{Acknowledgements}

This research is part of a $\mathrm{PhD}$ thesis funded by Irstea. Funding for this research and the extension project was provided by the Conseil Régional du Centre (France). We thank the French Forest Office (ONF Vierzon) and all the private forest owners for giving us access to their forests. We thank Vicki Moore for re-reading the English manuscript, Severine Delorme for answers to our questions about forest management, and our anonymous reviewers for their careful reading and valuable advice.

\section{Appendix A. Supplementary data}

Supplementary material related to this article can be found, in the online version, at http://dx.doi.org/10.1016/ j.baae.2016.04.005. 


\section{References}

Allombert, S., Gaston, A. J., \& Martin, J.-L. (2005). A natural experiment on the impact of overabundant deer on songbird populations. Biological Conservation, 126(1), 1-13.

Auer, S. K., \& Martin, T. E. (2013). Climate change has indirect effects on resource use and overlap among coexisting bird species with negative consequences for their reproductive success. Global Change Biology, 19(2), 411-419.

Barrios-Garcia, M. N., \& Ballari, S. A. (2012). Impact of wild boar (Sus scrofa) in its introduced and native range: A review. Biological Invasions, 14(11), 2283-2300.

Boulanger, V. (2010). Pression d'herbivorie et dynamique des communautés végétales: influence à court et moyen termes des populations de cervidés sur la diversité des communautés végétales en forêt ( $\mathrm{PhD}$ Thesis). Nancy: Université Henri Poincaré.

Boulanger, V., Baltzinger, C., Saïd, S., Ballon, P., Picard, J.-F., \& Dupouey, J.-L. (2009). Ranking temperate woody species along a gradient of browsing by deer. Forest Ecology and Management, 258(7), 1397-1406.

Bressette, J. W., Beck, H., \& Beauchamp, V. B. (2012). Beyond the browse line: Complex cascade effects mediated by white-tailed deer. Oikos, 1749-1760.

Chase, J. M., Leibold, M. A., \& Simms, E. (2000). Plant tolerance and resistance in food webs: Community-level predictions and evolutionary implications. Evolutionary Ecology, 14(4-6), 289-314.

Côté, S. D., Rooney, T. P., Tremblay, J.-P., Dussault, C., \& Waller, D. M. (2004). Ecological impacts of deer overabundance. Annual Review of Ecology, Evolution, and Systematics, 35, 113-147.

Cromsigt, J. P. G. M., \& Kuijper, D. P. J. (2011). Revisiting the browsing lawn concept: Evolutionary interactions or pruning herbivores? Perspectives in Plant Ecology, Evolution and Systematics, 13(3), 207-215.

DeCalesta, D. S. (1994). Effect of white-tailed deer on songbirds within managed forests in Pennsylvania. The Journal of Wildlife Management, 58(4), 711-718.

Díaz, S., Lavorel, S., McIntyre, S., Falczuk, V., Casanoves, F., Milchunas, D. G., et al. (2007). Plant trait responses to grazing - A global synthesis. Global Change Biology, 13(2), 313-341.

Donald, P. F., Fuller, R. J., Evans, A. D., \& Gough, S. J. (1998). Effects of forest management and grazing on breeding bird communities in plantations of broadleaved and coniferous trees in western England. Biological Conservation, 85(1-2), 183-197.

Dray, S., Choler, P., Dolédec, S., Peres-Neto, P. R., Thuiller, W., Pavoine, S., et al. (2013). Combining the fourth-corner and the RLQ methods for assessing trait responses to environmental variation. Ecology, 95(1), 14-21.

Fonderflick, J., Besnard, A., \& Martin, J.-L. (2013). Species traits and the response of open-habitat species to forest edge in landscape mosaics. Oikos, 122(1), 42-51.

Froissart, Y. (2011). Faire face aux engrillagements en Grande Sologne. Trans-Formation Consultants.

Fuller, R. J. (2001). Responses of woodland birds to increasing numbers of deer: A review of evidence and mechanisms. Forestry, 74(3), 289-298.

Fuller, R. J. (2013). Searching for biodiversity gains through woodfuel and forest management. Journal of Applied Ecology, 50(6), $1295-1300$.
Gebert, C., \& Verheyden-Tixier, H. (2008). Variations of diet composition of Red Deer (Cervus elaphus L.) in Europe. Mammal Review, 31(3-4), 189-201.

Genov, P. V., \& Massei, G. (2004). The environmental impact of wild boar. Galemys: Boletín Informativo de La Sociedad Española Para La Conservación Y Estudio de Los Mamíferos, 16(1), 135-145.

Gerhardt, P., Arnold, J. M., Hackländer, K., \& Hochbichler, E. (2013). Determinants of deer impact in European forests - A systematic literature analysis. Forest Ecology and Management, 310

Heinken, T., Schmidt, M., von Oheimb, G., Kriebitzsch, W.-U., \& Ellenberg, H. (2006). Soil seed banks near rubbing trees indicate dispersal of plant species into forests by wild boar. Basic and Applied Ecology, 7(1), 31-44.

Heinze, E., Boch, S., Fischer, M., Hessenmöller, D., Klenk, B., Müller, J., et al. (2011). Habitat use of large ungulates in northeastern Germany in relation to forest management. Forest Ecology and Management, 261(2), 288-296.

Hewson, C. M., Austin, G. E., Gough, S. J., \& Fuller, R. J. (2011). Species-specific responses of woodland birds to stand-level habitat characteristics: The dual importance of forest structure and floristics. Forest Ecology and Management, 261(7), 1224-1240.

Holt, C. A., Fuller, R. J., \& Dolman, P. M. (2010). Experimental evidence that deer browsing reduces habitat suitability for breeding Common Nightingales Luscinia megarhynchos. Ibis, 152(2), 335-346.

Holt, C. A., Fuller, R. J., \& Dolman, P. M. (2011). Breeding and postbreeding responses of woodland birds to modification of habitat structure by deer. Biological Conservation, 144(9), 2151-2162.

Holt, C. A., Fuller, R. J., \& Dolman, P. M. (2014). Exclusion of deer affects responses of birds to woodland regeneration in winter and summer. Ibis, 156(1), 116-131.

Kéry, M., \& Schaub, M. (2011). Bayesian population analysis using WinBUGS: A hierarchical perspective. Academic Press.

Low, M., Arlt, D., Eggers, S., \& Pärt, T. (2010). Habitat-specific differences in adult survival rates and its links to parental workload and on-nest predation. Journal of Animal Ecology, 79(1), 214-224.

Martin, J., Royle, J. A., Mackenzie, D. I., Edwards, H. H., Kéry, M., \& Gardner, B. (2011). Accounting for non-independent detection when estimating abundance of organisms with a Bayesian approach. Methods in Ecology and Evolution, 2(6), 595-601.

Mitchell, F. J. G., \& Kirby, K. J. (1990). The impact of large herbivores on the conservation of semi-natural woods in the British uplands. Forestry, 63(4), 333-353.

Morellet, N., Champely, S., Gaillard, J.-M., Ballon, P., \& Boscardin, Y. (2001). The browsing index: New tool uses browsing pressure to monitor deer populations. Wildlife Society Bulletin (1973-2006), 29(4), 1243-1252.

Morellet, N., \& Guibert, B. (1999). Spatial heterogeneity of winter forest resources used by deer. Forest Ecology and Management, 123(1), 11-20.

Newson, S. E., Johnston, A., Renwick, A. R., Baillie, S. R., \& Fuller, R. J. (2012). Modelling large-scale relationships between changes in woodland deer and bird populations. Journal of Applied Ecology, 49(1), 278-286.

ONCFS. (2012). Results from the annual French record of hunted animals. 
Robertson, B. A., Hutto, R. L., \& Fontaine, J. J. (2010). Evaluating food availability and nest predation risk as sources of bias in aural bird surveys. Journal of Field Ornithology, 81(4), 420-429.

Rooney, T. P., \& Waller, D. M. (2003). Direct and indirect effects of white-tailed deer in forest ecosystems. Forest Ecology and Management, 181(1-2), 165-176.

Royle, J. A. (2004). N-mixture models for estimating population size from spatially replicated counts. Biometrics, 60(1), 108-115.

Schaub, M., Martinez, N., Tagmann-Ioset, A., Weisshaupt, N., Maurer, M. L., Reichlin, T. S., et al. (2010). Patches of bare ground as a staple commodity for declining ground-foraging insectivorous farmland birds. PLOS ONE, 5(10), e13115.

Schley, L., \& Roper, T. J. (2003). Diet of wild boar Sus scrofa in Western Europe, with particular reference to consumption of agricultural crops. Mammal Review, 33(1), 43-56.

Schoener, T. W. (1971). Theory of feeding strategies. Annual Review of Ecology and Systematics, 2(1), 369-404.

Skarpe, C., \& Hester, A. J. (2008). Plant traits, browsing and gazing Herbivores, and vegetation dynamics. In I. J. Gordon, \& H. H. T. Prins (Eds.), The ecology of browsing and grazing (pp. 217-261). Berlin, Heidelberg: Springer.

Söderström, B., Pärt, T., \& Rydén, J. (1998). Different nest predator faunas and nest predation risk on ground and shrub nests at forest ecotones: An experiment and a review. Oecologia, 117(1-2), $108-118$.

Somers, M. J., \& Hayward, M. (2011). Fencing for conservation: Restriction of evolutionary potential or a riposte to threatening processes? Springer Science \& Business Media.

Svobodová, J., Koubová, M., Mrštný, L., Albrecht, T., \& Kreisinger, J. (2011). Temporal variation in nest predation risk along habitat edges between grassland and secondary forest in Central Europe. European Journal of Wildlife Research, 58(1), 315-323.

Teichman, K., Nielsen, S., \& Roland, J. (2013). Trophic cascades: Linking ungulates to shrub-dependent birds and butterflies. Journal of Animal Ecology, 82(6), 1288-1299.

Toms, J. D., Schmiegelow, F. K. A., Hannon, S. J., \& Villard, M.-A. (2006). Are point counts of boreal songbirds reliable proxies for more intensive abundance estimators? The Auk, 123(2), 438-454.

Tymkiw, E. L., Bowman, J. L., \& Shriver, W. G. (2013). The effect of white-tailed deer density on breeding songbirds in Delaware. Wildlife Society Bulletin, 37(4), 714-724.

Waller, D. M., \& Alverson, W. S. (1997). The white-tailed deer: A keystone herbivore. Wildlife Society Bulletin, 25(2), 217-226.

Wallis De Vries, M. F. (1995). Large herbivores and the design of large-scale nature reserves in Western Europe. Conservation Biology, 9(1), 25-33. 